\title{
Rater Competency in Conducting Performance Appraisal in the Malaysian Public Sector
}

\author{
Linda Hii and Rusli Ahmad
}

\begin{abstract}
The current performance appraisal system in the Malaysian public service (SSM) has placed heavy emphasis on rater competency in conducting the performance appraisal in a fair manner and to provide accurate ratings. The public sector has voiced out dissatisfaction with the SSM and the way it is being implemented. This study investigated raters' associated factors such as self-efficacy (PASE), knowledge (PSK), discomfort (PAD) which may impact rater competency. Rater PASE, PAD and PSK were found to significantly affect rater competency.
\end{abstract}

Index Terms-Performance appraisal self-efficacy, performance appraisal discomfort, perceived system knowledge, rater competency.

\section{INTRODUCTION}

Over the past decade, the Malaysian government has undertaken and implemented many administrative reforms to make its public service sector more efficient, effective and dynamic in response to the challenges of the changing environment and delivery of public services. These reforms have been largely driven by the desire to create a "quality culture" the public sector. Among these reforms is the public service remuneration system [1].

The New Remuneration System (SSB) introduced in 1992 brought major changes to the public remuneration system. It was a performance-based system with a long term strategic measure to enhance the effectiveness and quality of the public service. Due to widespread dissatisfaction, feedback and negative views, the SSB was subsequently replaced by the Malaysian Remuneration System (SSM) in November 2002 after 10 years of implementation. The only changes were made in the remuneration, terms and conditions of service and administrative procedures in the public service The SSM essentially is a competency-based HRM in the public service [2]. Civil servants are encouraged to acquire competencies such as knowledge, skills, expertise, experience, positive attitudes and right attitude in order to remain relevant to the public service and be able to cope with national and global challenges [3].

In spite of the reforms made, the public sector in Malaysia continues to suffer from a decline in efficiency and organizational competence. Morale was low as civil servants were discontented and had grievances about the way it was

Manuscript received August 15, 2013; revised October 16, 2013

Linda Hii is with the Department of Marketing and Management, Curtin University, Sarawak Campus, Malaysia (e-mail: linda.hii@ curtin.edu.my).

Rusli Ahmad is with the Development Centre, Student Affair and Alumni Division (BHEPA), University Malaysia Sarawak (UNIMAS), Malaysia (e-mail: arusli@ppp.unimas.my). implemented. Several issues have arisen since the effective performance appraisal [4]. The competencies found lacking were knowledge, skills, expertise, experience and positive attitude. These assessors did not have a clear understanding of the philosophy, aims and objectives behind the SSM. Many were not given training on how to conduct the performance appraisal exercise. Civil servants expressed dissatisfaction over no feedback interview and justification for the performance gap [4].

The above seems to suggest that core of the problem lies mostly with the raters and implementation of appraisal system. This research intends to investigate rater performance appraisal self-efficacy (PASE), performance appraisal discomfort (PAD) and their perceived system knowledge of the appraisal system (PSK) impact their rating competency.

\section{THEORETICAL MODEL}

The theoretical model (Fig. 1) was developed to hypothesize and test the relationships between rater PASE, PAD and PSK of the appraisal system (independent variables) and rater competency (dependent variable). The hypotheses tested in this study are graphically shown in Fig. 1.

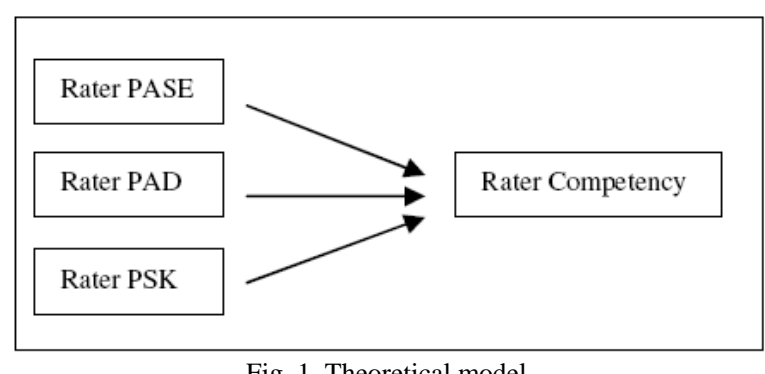

Fig. 1. Theoretical model.

\section{LITERATURE REVIEW}

\section{A. Performance Appraisal System Studies}

Past researches on performance appraisal have studied on rater errors [5], the influence of organizational context on raters' behavior [6]-[8] and rating inaccuracy [9]. All these studies share one common theme - i.e. the tasks associated with the production of performance appraisal ratings are often difficult to accomplish within the complex and dynamic environment of most work contexts [10].

A review of literature also reveals numerous rater-related factors which have influenced performance ratings: for example, raters' self-efficacy (see [11], self-monitoring (see [7], [8], [12], [13]) and rater trust or confidence in the 
appraisal system (see [8], [14]). A frequently studied factor is rater orientation to performance appraisal such as PAD (see [8] and [15]-[17]. Others have focused on accountability (see [10], [14]; PSK [18], perceived use(s) of performance appraisal [19], perceived effectiveness of performance appraisal [20]. The amount and level of training received and experience on the task are also said to be factors that influence rating accuracy [21]. Research on raters' or managerial competencies has also received much attention (see [22], [23]).

Raters' perceptions of the broader organizational context (like organizational climate) and attitudes towards the organizations are also thought to affect raters indirectly (see [7], [8]). A participatory climate, for example, characterized by cooperative relationships, individual responsibility, trust and communication is said to be conducive to both the high levels of performance and effective PA. Other studies have looked at the role of the supervisor or manager placed in the challenging role of a rater. Raters must have the competencies, skills and motivation to conduct effective performance appraisals [24].

Several studies conducted in the Malaysian public sector showed great discrepancy between policy and practice of SSM. The PPPs and PPKs were found not to follow the guidelines stipulated by the Public Service Department (PSD) and did not provide feedback to their subordinates. This has become a cause for grievances and discontent against raters. A study on the Royal Malaysia Police (RMP) found rampant non-compliance with specific guidelines [25]. The most profound finding was $93 \%$ of the respondents surveyed felt their appraisers need training implying the importance of rating skills/ competencies. Majority of the respondents were not happy as the annual work targets were not set according to schedule $(76 \%)$; there was no performance counseling during the entire process $(68 \%)$ and that the appraisal was done at the last minute $(65 \%)$. The subordinates were not informed of the result of their appraisals. There were many drawbacks in the implementation of the appraisal system in Malaysian schools [26]. The lack of competency, little focus on the appraisal mechanism, and heavy workload of the principal and his/her management team are some of the reasons for the poor implementation of the appraisal system. For effective performance appraisal, they recommended that the evaluators be well versed and competent in the appraisal mechanism. A cross section study conducted on Public Health Physicians found $80.6 \%$ of PPKA did not agree with implementation of SSM [27]. The major findings were: ambiguity of the procedure $(83.9 \%)$, the Competency Assessment Level tests were not relevant (54.1\%) and appraisees' promotion affected (40.5\%). Another study explored the competency of the Malaysian public sector information officers who managed the information technology matters of government ministries and departments [28]. It proposed a system namely SPeK PSM (Information officers competency assessment system) to identify the IT officers' competency gap. The justification for this study was that IT personnel, particularly in the public agencies, have to update their knowledge in order to improve their skills and upgrade their competencies to keep up with current technologies that are evolving continuously.

\section{B. Performance Appraisal Self-efficacy (PASE)}

PASE is an important construct in organizational behavior because of its impact in motivational processes and goal attainment [9], [8], [34]. Self-efficacy refers to the degree to which the rater believes he has the necessary skills to perform the task well [34]. Specifically, human behavior is more often determined by individuals' subjective beliefs in their ability to perform, rather than from objective conditions. Moreover, research consistently has established a positive link between self-efficacy and work-related performance, such as managerial decision-making and coping with stressful events [35], [36]. Similarly, research suggests that self-efficacy enhances the individual's propensity to strive toward desired goals, as well as to persist on difficult tasks [34], [37].

Earlier research has suggested raters differ in the degree to which they believe they have the necessary skills to perform the task of performance appraisal accurately [31]. Raters with a high level of self-efficacy may be expected to perform the appraisal task more conscientiously [38]. The widespread belief that performance appraisal is futile may not always reflect a lack of self-efficacy, but rather reflect their assessment of how appraisal systems work in organizations [33].

It has been argued that raters' beliefs regarding their ability to rate accurately (i.e., rater self-efficacy, perceived ability to rate) will influence rating quality [11]. Studies have found raters with high self-efficacy tend to rate others more accurately than those with low self-efficacy (e.g., [7], [30], [31]). Unfortunately, research findings are inconsistent. For example, although rater self-efficacy has related positively to rater ability to discriminate among ratees [32], rater self-efficacy has also been shown to be related positively [12], negatively [33], and not at all [32] with rater ability to discriminate among rating dimensions. Moreover, rater self-efficacy has related both negatively [33] and positively [12], [32] to rating level (i.e., rating leniency).

\section{Performance Appraisal Discomfort (PAD)}

Studies have found raters often report they are uncomfortable with having to monitor and evaluate subordinates' performance, and provide them with feedback (e.g., [7], [8]. Raters who show high levels of appraisal discomfort tend to give more lenient ratings and are less likely to distinguish among subordinates [39]. Presumably, by giving uniformly high appraisal, they can avoid the potentially unpleasant consequences of assigning high ratings to some subordinates and low ratings to others. It was found raters with a high level of trust are also likely to feel comfortable giving their subordinates feedback, to be more discerning, and to be better able to distinguish stronger from weaker performers [7]. Three factors that are likely to predict rater discomfort in a variety of performance appraisal situations are: a social context (beliefs about the importance of performance appraisal), rater characteristics (e.g., communication style, age, and experience), and the length of the ratee-rater relationship [40].

In the performance appraisal context, the organization 
helps to shape the rater's perceptions of the importance of performance appraisals and hence his or her appraisal attitudes and behaviors [41], [42].The extent to which the organization values its performance appraisal system is communicated through how appraisals are carried out (e.g., rater accountability) and how the rating outcomes are used.

For example, if raters are held accountable and ratings play a key role in personnel actions such as pay increment and promotion, the organization has, in part, communicated the importance of appraisals. Raters who have to account for the ratings they give to their subordinates experience a certain level of discomfort. These social cues are likely to heighten rater perceptions of the importance of performance appraisals and, in turn, increase their levels of performance appraisal discomfort [40]. Vast literature reported on raters' discomfort to monitor and evaluate subordinates' performance and provide them with feedback (see [7], [17], [32]). Conveying good news is less stressful and difficult than conveying bad news to subordinates [43]. It was suggested that raters who show high levels of appraisal discomfort are more likely to provide inflated ratings and less likely to distinguish among subordinates [39]. Raters who give uniformly high ratings can avoid the potentially unpleasant consequences of assigning high ratings to some subordinates and low ratings to others [8].

\section{Perceived System Knowledge (PSK)}

Supervisory employees have different perspectives from which to judge and understand the PAS, which implies they have different levels of knowledge of the appraisal system [44], [45]. A PSK scale was developed which measures the level of understanding and knowledge an employee reports having about the standards, criteria, and objectives of his/her performance appraisal system [18]. Thus it is reasonable to predict supervisory employees who have PSK of the PAS will be able to conduct the performance appraisal more competently and are more compliant to conduct the appraisal accurately. Based on this reasoning, the following hypotheses are developed:

Perceived system knowledge (PSK) refers to the level of understanding and knowledge an employee has about the standards, criteria and objectives of the performance appraisal system in his organization [46]. It was found individuals with higher levels of understanding about the appraisal system reported higher level of satisfaction with the performance appraisal system in their organization [47]. There have also been earlier studies that supported supervisory employees' enhanced experience with the system provides them with a unique perspective and knowledge that may influence how they react and evaluate the appraisal system (e.g. [44], [45]). In the development of the PSK construct, and [18] suggested that the extent to which individuals believe that they understand the overall role and process of the organization's performance appraisal may be very important in determining how they view the organization in general and the appraisal process in particular.

\section{E. Rater Competency}

In human resource management, especially performance appraisal, competency analysis is used to inform and improve the processes of recruitment and selection, job design, performance management, employee development and employee reward [48]. Competent appraisals require both skills and the motivation to be able to conduct appraisals effectively [7]. Simply, the competency approach refers to a process of analyzing the key aspects of behavior that differentiate between effective and less effective performance.

A review of literature shows competence is largely defined in terms of the desire to see specific work-related behavior very clearly [49]. There are six clusters of competencies that are related to managerial effectiveness: goal and action management cluster, leadership cluster, human resource management cluster, directing subordinate cluster, focus on others cluster, and specialized knowledge [50]. Competency is the capacity to transfer skills and abilities from one area to another [51]. Ten rater skills are necessary to effectively conduct formal performance appraisals at four integrated phases in the performance appraisal process [52]. Among the ten skills identified are: knowledge of the appraisal system, delegation, coaching, conflict resolution, knowledge of legal and compliance issues. The underlying skill at all four phases of the appraisal process is an effective two-way communications skill.

\begin{tabular}{|llr|}
\multicolumn{3}{|c|}{ TABLE I: KMO AND BARLETT'S TEST TABLE } \\
\hline KMO Measure of Sampling Adequacy. & 0.948 \\
Bartlett's Test of Sphericity & Approx. & 15254.088 \\
& Chi-Square & \\
& df & 1326 \\
Sig & 0.000 \\
\hline
\end{tabular}

\section{HYPOTHESES}

Based on the literature review, the following research hypotheses are proposed:

H1: Rater PASE will predict rater competency positively.

$\mathrm{H} 2$ : Rater PAD will predict rater competency.

H3: Rater PSK of the appraisal system will predict rater competency positively.

H4: Rater PASE, PAD and PSK contribute significantly to rater competency.

\section{Methodology}

A self-report questionnaire was used to survey raters/assessors in the Malaysian public service in government ministries, departments, and agencies, institutions of higher learning, schools and statutory bodies in Sarawak. 600 questionnaires were issued and 419 were returned. Data screening was done to check for missing values resulting in 347 usable questionnaires for data analysis. The assessors are the PPPs (Pegawai Penilaian Pertama) and PPKs (Pegawai Penilai Kedua) who are senior government officials such as directors, deputy directors, heads of departments / sections / agencies; principals, assistant principals, etc. They are raters by virtue of the positions they hold. 
The self-report questionnaire consists of questions which respondents rate their responses on a 5-point anchor Likert scale ranging from 1 = "Strongly Disagree', 2 = "Disagree", 3 = "Undecided", 4 = "Agree" and 5 = "Strongly Agree" in almost all measurements unless specified to rank the respondent's response to a certain item or attitude. A sample question is: "I understand the performance appraisal system being used in my organization". Respondents indicate how strongly they disagree or agree with statements that range from very positive to very negative toward the attitudinal object.

The measurement scales for all the constructs were adapted from past studies which indicated high reliability: PASE $(\alpha=0.94)$ [10]; PSK $(\alpha=0.89)$ [18] and PAD $(\alpha=0.90)$ [40]. The rater competency original scale [52] used a 3-point anchor scale of $1=$ "Not at all", 2 = "To some extent" and 3 ="To a great extent". To standardize the scale, the scale was changed to a 5-point Likert scale as mentioned above. To ensure validity and reliability of the scales, reliability was conducted again after obtaining the data.

\section{DisCUSSION AND RESULTS}

Kaiser-Meyer-Olkin (KMO) is 0.948, which indicates sampling adequacy greater than 0.5 [57] and justifies a satisfactory factor analysis to proceed. Bartlettt's Test of Sphericity (15254.088) is also significant $(p=0.000)$ which means the variables are strongly correlated again supporting a factor analysis can proceed (Table I).

Reliability was overall very good for all the measurement scales: PASE ( $\alpha=0.931)$; PSK $(\alpha=0.899)$; PAD $(\alpha=0.926)$ and rater competency $(\alpha=0.949)$. A principle component analysis (PCA) using varimax rotation was conducted on all the constructs (46 items). Communalities varied from .716 to .404 again evident of strong correlation. Applying the Kaiser's Rule and the screen test, five factors emerged. Following varimax rotation, Factor 1 loaded on 13 items that reflected Competency and accounted for $36.34 \%$ of the variance exemplified by the two highest loading items: COMP 7 (0.788) and COMP 8 (0.784). Factor 2 reflected PAD (PAD 1-8, $13 \&$ 15) which accounted for $9.1 \%$ of the total variance explained and accounted for 9 items. Factor 3 reflected PASE and loaded on all its original items. It explained $6.1 \%$ of the total variance. Factor 4 reflected PSK and loaded with all the original 9 items with a total variance of $4.5 \%$. Factor 5 (PAD 9-12 \& 14) which accounted for only $2.8 \%$ of the total variance explained was removed. The remaining 41 factors that emerged were further explored for validity through regression.

\section{Data Analysis And Hypotheses Testing}

Regression equation:

- Rater Competencies $=\alpha+\beta_{1} \mathrm{PASE}+\beta_{2} \mathrm{PAD}+\beta_{3} \mathrm{PSK}$ $+e_{1}$

- $\quad$ PASE = Performance appraisal self-efficacy

- $\mathrm{PAD}=$ Performance appraisal discomfort
- $\quad$ PSK = Perceived system knowledge

- $e^{1}=$ error term

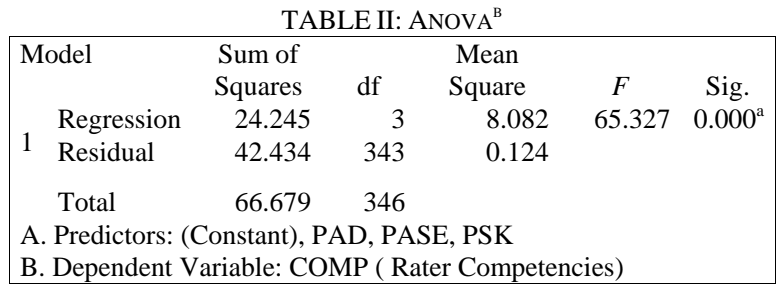

From the model summary table (Table IV), linear regression validates the regression model. The overall model fit is significant ( $p=0.000$ ) (Table II) and the effect size is $\mathrm{R}^{2}$ $=0.364$. The model explains $36 \%$ of the variance in Rater Competencies. $F$ statistics is $24.245 / 0.124$ at $3,343=$ $65.327>1$ (see Table II). Therefore the global null hypothesis is rejected. The $\mathrm{F}$ value is more than 1 and thus is significant. This indicates there are differences in group means indicating the predictors have an effect on rater competencies. The regression model (Table III) is significant at $p=0.000$. Overall, there is a significant relationship between the predictors (PASE, PAD and PSK) on rater competencies. The results show all three predictors are significant. Thus Hypotheses 1, 2, 3 and 4 are supported.

\begin{tabular}{|c|c|c|c|c|c|c|}
\hline \multicolumn{7}{|c|}{ TABLE III: COEFFICIENTS ${ }^{\text {A }}$} \\
\hline & & \multicolumn{2}{|c|}{$\begin{array}{c}\text { Unstandardized } \\
\text { Coefficients }\end{array}$} & \multirow{2}{*}{$\begin{array}{c}\begin{array}{c}\text { Standardized } \\
\text { Coefficients }\end{array} \\
\text { Beta }\end{array}$} & \multirow[b]{2}{*}{$t$} & \multirow[b]{2}{*}{ Sig. } \\
\hline \multicolumn{2}{|c|}{ Model } & $B$ & $\begin{array}{l}\text { Std. } \\
\text { Error }\end{array}$ & & & \\
\hline \multirow[t]{4}{*}{1} & (Constant) & 1.300 & 0.198 & & 6.556 & 0.000 \\
\hline & PASE & 0.144 & 0.049 & 0.158 & 2.953 & 0.003 \\
\hline & PSK & 0.370 & 0.055 & 0.378 & 6.685 & 0.000 \\
\hline & PAD & 0.164 & 0.038 & 0.206 & 4.347 & 0.000 \\
\hline
\end{tabular}

\begin{tabular}{|c|c|c|c|c|}
\hline \multicolumn{5}{|c|}{ TABLE IV: MODEL SUMMARY ${ }^{\mathrm{B}}$} \\
\hline Model & $R$ & $R^{2}$ & Adjusted $R^{2}$ & $\begin{array}{l}\text { Std. Error of } \\
\text { the Estimate }\end{array}$ \\
\hline 1 & $0.603^{\mathrm{a}}$ & 0.364 & 0.358 & 0.35173 \\
\hline \multicolumn{5}{|c|}{ A. Predictors: (Constant), PAD, PASE, PSK } \\
\hline B. De & ent Var & ble: C & MP ( Rater C & petencies) \\
\hline
\end{tabular}

\section{CONCLUSION AND RECOMMENDATIONS}

From the results, it is evident that the three predictors: PASE, PAD and PSK show significant relationship with rater competencies. The findings suggest that self-efficacious raters and raters who understand clearly the performance appraisal system are confident and perceive themselves as competent raters. According to [53], raters must have the competencies, skills and motivation to conduct effective performance appraisals. The findings also suggest that how organizations manage and implement their performance appraisal system will influence the employees' reactions towards the system and organization [54]. The findings could serve as input to policy makers and HR practitioners.

As indicated earlier, the PPPs and PPKs did not follow the guidelines stipulated by the PSD and did not provide feedback to their subordinates could be because they are not 
confident of their self-efficacy, are uncomfortable with conducting performance appraisal or may not have sufficient knowledge of the system itself. It is suggested that appropriate training be given to the PPPs and PPKs. This study also hints to the importance of feedback culture be inculcated in the Malaysian public service [55]. A feedback culture is characterized by managers and employees feeling comfortable both providing and receiving feedback [56]. This would reduce the stress associated with performance appraisal discomfort.

\section{LIMITATIONS OF STUDY}

This study is limited to only samples from civil service officials in Sarawak and may not completely reflect the population. Sampling could be extended to include the other Malaysian states. There are several other rater-related factors which were not studied and not included in this research due to limited time and cost constraints

\section{REFERENCES}

[1] M. Shah and S. L. Liew, "Model kompetensi dan perkhidmatan awam Malaysia," Journal Pengurusan Awam, vol. 1, no. 2, pp. 1-15, 2002.

[2] Public Service Department (PSD), "Human resource development in the public service-Malaysian experience," presented at the 13th ACCSM Main Conference, Phnom Penh, Cambodia, December 20-22, 2005.

[3] S. Osman. (October 7, 2003). Speech at The CAPAM high level seminar reception dinner. [Online]. Available: http://www.pmo./gov.my

[4] R. Ahmad, N. A. Ismail, and W. Khairuzzaman, "Sistem penilaian prestasi sektor awam di Malaysia: Pemikiran semula terhadap peranan dan tanggungjawab pegawai penilai prestasi," Journal Kemanusiaan, vol. 1, 2007.

[5] T. Murphy and J. Margulies, "Performance appraisal," presented the ABA Labor and Employment Law Section Equal Employment Opportunity Committee, Mid-winter Meeting, March, 2004.

[6] J. N. Cleveland and K. R. Murphy, "Analyzing performance appraisal as goal-directed behavior," in Proc. Research in personnel and human resources management, G. Ferris and K. Rowland, Eds., Greenwich, CT: JAI Press, 1992, ch. 10, pp. 121-185.

[7] K. R. Murphy and J. N. Cleveland, Understanding Performance Appraisal - Social, Organizational and Goal-Based Perspectives, Sage Pub, 1995.

[8] A. Tziner, K. Murphy, J. N. Cleveland, A. Yavo, and E. Hayoon, “A new old question: Do contextual factors relate to rating behavior: An investigation with peer evaluations," International Journal of Selection and Assessment, vol. 16, no. 1, pp. 59-67, 2008

[9] A. Tziner, K. Murphy, and J. N. Cleveland, "Contextual and rater factors affecting rating behavior," Group and Organization Management, vol. 30, no. 1, pp. 89-98, 2005.

[10] R. E. Wood and V. Marshall, "Accuracy and effectiveness in appraisal outcomes: the influence of self-efficacy, Personal factors and organizational variables," Human Resource Management Journal, vol. 18, no. 3, pp. 295-313, 2008.

[11] J. D. Kudisch, V. J. Fortunato, and A. F. Smith, "Contextual and individual difference factors predicting individuals' desire to provide upward feedback," Group Organization Management, vol. 31, pp. 503 , 2006.

[12] A. Tziner and K. R. Murphy, "Additional evidence of attitudinal influences in performance appraisal," Journal of Business and Psychology, vol. 13, no. 3, 1999.

[13] I. M. Jawahar, "Attitudes, self-monitoring, and appraisal behaviors," Journal of Applied Psychology, vol. 86, no. 5, pp. 875-883, 2001.

[14] R. K. Robinson, R. L. Fink, and B. M. Allen, "The influence of organizational constituent groups on rater attitudes toward performance appraisal compliance," Public Personnel Management, vol. 25 , no. 2 , pp. $141-150,1996$.
[15] H. J. Bernardin, S. A. Dahmus, and R. L. Sims, "Rater leniency and performance appraisal discomfort," Educational and Psychological Measurement, vol. 53, no. 3, pp. 789-799, 1993.

[16] W. J. Smith, K. V. Harrington, and J. D. Houghton, "Predictors of performance appraisal discomfort: A preliminary examination," Public Personnel Management, vol. 29, no. 1, pp. 21-32, 2000.

[17] K. Murphy, J. Cleveland, and C. Mohler, "Reliability, validity and meaningfulness of multisource ratings," in Handbook of Multi Source Feedback, D. Bracker, C. Timmreck, and A. Church, Eds. San Francisco: Jossey-Bass, 2001, pp. 130-148.

[18] J. R. Williams and P. E. Levy, "The effects of perceived system knowledge on the agreement between self-ratings and supervisor ratings," Personnel Psychology, vol. 45, pp. 835-847, 1992.

[19] C. O. Longenecker and J. S. Goff, "Performance appraisal effectiveness: A matter of perspective," SAM Advanced Management Journal, pp. 17-23, 1992.

[20] S. F. C. Sekhar, "Assessment of effectiveness of performance appraisal system: Scale development and its use," Siva Sivani Institute of Management, vol. 3, no. 4, pp. 1-6, 2007.

[21] D. J. Woehr and A. I. Huffcutt, "Rater training for performance appraisal: A quantitative review," Journal of Occupational and Organizational Psychology, vol. 67, pp. 189-205, 1994.

[22] U. Rajadhyaksha, "Managerial competence: Do technical capabilities matter?" VIKALPA, vol. 30, no. 2, 2005.

[23] S. Agut, R. Grau, and J. M. Peiro,"Competency needs among managers from Spanish hotels and restaurants and training demands," International Journal of Hospitality Management, vol. 22, no. 3, pp. 281-295, 2003.

[24] C. O. Longenecker and J. S. Goff, "Performance appraisal effectiveness: A matter of perspective," SAM Advanced Management Journal, pp. 17-23, 1992.

[25] D. Kumar, "Performance appraisal: The importance of rater training," Journal of the Kuala Lumpur Royal Malaysia Police College, vol. 4, 2005.

[26] S. Malakolunthu and N. Malek, "Teachers performance evaluation system: reality and challenges," Masalah Pendidikan, vol. 31, no. 1, pp. 215-230, 2008.

[27] A. Ismail, S. M. Aljunid, and M. Jamsiah, "Persepsi pakar perubatan kesihatan awam, kementerian kesihatan Malaysia mengenai skim Sistem Saraan Malaysia (SSM),"Journal of Community Health, vol. 13, no. 1,2007

[28] N. A. Manaf, Z. Abu Bakar, and Z. M. Yusof, "SPeK PSM Competency assessment system for Malaysian public sector information officers," presented at the International Conference on Electrical Engineering and Informatics, Bandung, Indonesia, June, 2007.

[29] A. Bandura, "Self-efficacy: toward a unifying theory of behavorial change," Psychological Review, vol. 84, pp. 191-215, $1977 \mathrm{~b}$.

[30] A. M. Mohrman and E. E. Lawler, "Motivation and performance-appraisal behaviour," in Performance Measurement and theory, F. Landy and S. Zedeck, Eds. Hillsdale, N.J.: Erlbaum, 1983, pp. 173-189.

[31] N. Napier and G. P. Latham, "Outcome expectancies of people who conduct performance appraisals," Personnel Psychology, vol. 39, pp. 827-837, 1986.

[32] A. Tziner, K. R. Murphy, and J. N. Cleveland, "Does conscientiousness moderate the relationship between attitudes and beliefs regarding performance appraisal and rating behavior?" International Journal of Selection and Assessment, vol. 10, pp. 218-224, 2002.

[33] A. Tziner, K. R. Murphy, J. N. Cleveland, G. Beaudin, and S. Marchand, "Impact of rater beliefs regarding performance appraisal and its organizational contexts on appraisal quality," Journal of Business and Psychology, vol. 12, pp. 457-467, 1998.

[34] A. Bandura, Social learning theory, Englewood Cliffs, New Jersey: Prentice-Hall, 1977a.

[35] S. A. Stumpf, A. P. Brief, and K. Hartman, "Self-efficacy expectations and coping with career-related events," Journal of Vocational Behavior, vol. 31, pp. 91-108, 1987.

[36] A. Bandura and R. Wood, "Effect of perceived controllability and performance standards on self-regulation of complex decision making," Journal of Personality and Social Psychology, vol. 56, no. 5, pp. 805-814, 1989.

[37] M. R. Leary and D. L. Downs, "Interpersonal functions of the self-esteem motive: The self-esteem system as a sociometer," in Efficacy, Agency, and Self-Esteem, M. H. Kernis (Ed.), New York: Plenum Press, pp. 123-144, 1995. 
[38] H. J. Bernardin and P. Villanova, "Research streams in rater self-efficacy," Group and Organization Management, vol. 30, pp. 61-88, 2005.

[39] P. Villanova, H. J. Bernardin, S. A. Dahmus, and R. L. Sims, "Rater leniency and performance appraisal discomfort," Educational and Psychological Measurement, vol. 53, pp. 789-799, 1993.

[40] W. J. Smith, K. V. Harrington, and J. D. Houghton, "Predictors of performance appraisal discomfort: A preliminary examination," Public Personnel Management, vol. 29, no. 1, pp. 21-32, 2000.

[41] T. A. Judge and G. R. Ferris, "Social context performance evaluation decisions," Academy of Management Journal, vol. 36, pp. 80-105, 1993.

[42] W. F. Giles and K. W. Mossholder, "Employee reactions to contextual and session components of performance appraisal," Journal of Applied Psychology, vol. 75, pp. 371-377, 1990.

[43] S. P. Robbins, Personnel: The Management of Human Resources, $2^{\text {nd }}$ ed, New Jersey: Prentice-Hall Int., 1982.

[44] M. K. Mount, "Comparisons of supervisory and employee satisfaction with a performance appraisal system," Personnel Psychology, vol. 36, pp. 99-110, 1983.

[45] A. Pooyan and B. J. Eberhard, "Correlates of performance appraisal satisfaction among supervisory and nonsupervisory employees," Journal of Business Research, vol. 19, pp. 215-226, 1989.

[46] J. R. Williams and P. E. Levy, "Investigating some neglected criteria: the influence of organizational level and perceived system knowledge on appraisal reactions," Journal of Business and Psychology, vol. 14, no. 3, pp. 501-513, 2000 .

[47] P. E. Levy and J. R. Williams, "The role of perceived system knowledge in predicting appraisal reactions, job satisfaction and organizational commitment," Journal of Organizational Behavior, vol. 19, pp. 53-65, 1998.

[48] M. Armstrong, Performance Management, London: Kogan, 1994.

[49] D. Hornby and R. Thomas, "Towards a better standard of management," Personnel Management, vol. 21, no. 1, pp. 52-55, 1989

[50] R. E. Boyatzis, The Competent Manager, Chichester: John Wiley and Sons, 1982.

[51] B. Hogg, "The AMA Competency Programme," in Development Centers: Realizing the Potential of Your Employees through
Assessment and Development, L. Geoff and D. Beard, Eds., London: The Tata-McGraw-Hill Training Series, 1989.

[52] S. Fink and C. O. Longenecker, "Training as a performance appraisal improvement strategy," Career Development International, vol. 3, no. 6, 1998.

[53] C. O. Longenecker, "Truth or consequences: Politics and performance appraisals," Business Horizons, vol. 32, pp. 76-82, 1989.

[54] D. R. Ilgen, J. L. Barnes-Farrell, and D. B. Mckellin, "Performance appraisal process research in the 1980s: What has it contributed to appraisals in use?" Organizational Behavior and Human Decision Processes, vol. 54, pp. 321-368, 1993.

[55] T. J. Maurer, D. Mitchell, and F. G. Barbeite, "Predictors of attitudes toward a 360-degree feedback system and involvement in post-feedback management development activity," Journal of Occupational and Organizational Psychology, vol. 75, pp. 87-107, 2002.

[56] M. London, Job Feedback, Mahwah NJ: LEA, 2003.

[57] R. B. Burns and R. A. Burns, Business Research Methods and Statistics Using SPSS, Los Angeles: SAGE, 2008.

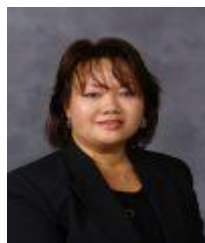

Linda Hii is a senior lecturer at the school of business, Curtin University Sarawak, Malaysia. Her research interests are performance management system, performance appraisal, human resources management and leadership issues.

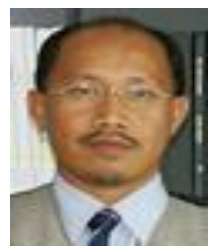

Rusli Ahmad is the dean of student development centre student affair and alumni division (BHEPA) Curtin University Sarawak, Malaysia. His research interests are performance management system, performance appraisal, training and development, cognitive processing and leadership issues. 